\title{
Study on the Innovative Talents in Wuhan Industry in the Transformation and Upgrading Period
}

\author{
Zhihong Li \\ Business School Jianghan University Wuhan, Hubei, China,430056 \\ email: linanwudingbang@163.com
}

Keywords: Wuhan; Transformation and upgrading; Talent development

\begin{abstract}
The 12th Five-Year Plan is the important period of the transformation and upgrading of the industry in Wuhan and the time to further lay its foundation. The success in the industrial transformation and upgrading depends on the talents, especially on those with innovative spirits and courage. Aimed at this issue, the paper comprehensively analyzes the actual situation in developing the industrial talents in Wuhan in the comparative research method, expounds the features in using them and put forward some measures to develop and adopt rationally the innovative talents.
\end{abstract}

\section{Introduction}

The transformation and upgrading of the industry in Wuhan means the changes from the extensive development pattern mainly based on consuming resources and energies to the intensive one just on technology and innovation to save resources and energies, to the new commerce-serving one. It may see a process of denying self and its main form is to give up the old and set up the new. It may be a pain for the enterprises that have been accustomed to the old productive pattern and management form. Therefore, an urgent need for the personnel who is both innovative and courage and resourceful exists in the enterprises. To develop this kind of personnel includes the formal schooling education, the training either from society or firms, but all this still stays in the stage to foster the potential talent and some distance occurs in comparison with the connotation of the real talent. In light of the "Mid-Long Term Planning Outline to Develop Talents in China (2010-2020)", talents are defined as "those that are holding certain specialty or expertise, making contributions to the society by their creative labor and the laborers with higher ability and qualification among the human resources. Talents are the first resources in developing the national economy and society". As for the industrial enterprises, how to transform their human resources into talents should lie in the use of them in which their ability and intelligence can be fully deployed and contributions to the enterprises or society realized. In this way, the paper focuses its study on the use of the talents such as inputs, outputs, projects and institutions of the $R \& D$ personnel in developing the innovative industrial talents in Wuhan.

\section{Actual Situation in Developing R\&D Talents in Wuhan Industry}

Inputs into R\&D: In the personnel that join in the $R \& D$, in 2009, the industry in Wuhan has 31092 researchers that quadruple that of 2000. Calculated according to the actual working time, full time equivalent of R\&D staffs is 20709 and 4.6 times of that in 2000.

In 2009, the inputs into R\&D by the industrial enterprises in Wuhan were 6.4 billion yuan and 10.6 times bigger than those in 2000 with an average yearly increase of 30\%. The input intensity into $R \& D$ by the industrial enterprises was $1.07 \%$ and rose by 0.3 percentage higher than that in 2000 , of which the medium and big enterprises invested 5.82 billion yuan into R\&D with an intensity of $1.18 \%$ which was raised 0.45 percentage compared with that of 2000 .

In the industry in Wuhan, the input intensity into $R \& D$ of the manufacturing industry was 6.35 billion yuan, occupying $99.2 \%$ of the total industries (see Table I). The industries ranked the top ten were respectively telecommunication equipment, computer and other electronic equipments, instrumentation and cultural and office machinery manufacturing equipments, general equipment manufacturing, ferrous metal smelting and rolling processing, chemical materials and chemical 
products manufacturing, pharmaceutical manufacturing, manufacture of electrical machinery and equipments, transportation equipment manufacturing, metal products.

TABLE I. INPUT INTO R\&D BASED ON INDUSTRIES

\begin{tabular}{|c|c|c|c|c|c|c|c|}
\hline Industries & $\begin{array}{l}\text { Inputs ( } 1 \\
\text { thousand } \\
\text { yuan) }\end{array}$ & $\begin{array}{l}\text { 0Input } \\
\text { intensity } \\
(\%)\end{array}$ & Place & Industries & $\begin{array}{l}\text { Inputs ( } \\
\text { thousand } \\
\text { yuan) }\end{array}$ & $\begin{array}{l}10 \text { Input } \\
\text { intensity } \\
(\%)\end{array}$ & Place \\
\hline Total & 639891.4 & 1.07 & & Non metallic mineral products & 3929.5 & 0.38 & 13 \\
\hline Manufacturing industry & 634798.5 & 1.23 & & $\begin{array}{l}\text { Ferrous metal smelting and rolling } \\
\text { processing }\end{array}$ & 210073.3 & 1.45 & 5 \\
\hline Agriculture food processing & 702.8 & 0.05 & 22 & $\begin{array}{l}\text { Nonferrous metal smelting and } \\
\text { rolling processing }\end{array}$ & 69.4 & 0.03 & 23 \\
\hline Food manufacturing & 1191.9 & 0.18 & 14 & Metal products & 9228.6 & 0.81 & 10 \\
\hline Tobacco manufacturing & 14215.8 & 0.54 & 12 & General equipment manufacturing & 37695.4 & 2.18 & 3 \\
\hline Textile & 556.8 & 0.13 & 15 & Special equipment manufacturing & 21880.1 & 2.04 & 4 \\
\hline Paper making and products & 226.7 & 0.05 & 21 & $\begin{array}{ll}\text { Transportation } \\
\text { manufacturing }\end{array}$ & 113122.9 & 1.05 & 9 \\
\hline Printing, etc & 2626.2 & 0.69 & 11 & $\begin{array}{l}\text { Manufacture of electrical machinery } \\
\text { and equipment }\end{array}$ & 33751.4 & 1.18 & 8 \\
\hline \begin{tabular}{|l|} 
Culture, education \\
And sports goods
\end{tabular} & 16.3 & 0.12 & 16 & $\begin{array}{l}\text { Electronic and communication } \\
\text { equipment manufacturing }\end{array}$ & 149680.3 & 2.63 & 1 \\
\hline $\begin{array}{l}\text { Petroleum , coking and nuclear } \\
\text { fuel processing }\end{array}$ & 82.9 & 0.004 & 24 & $\begin{array}{l}\text { Instrumentation } \\
\text { supplies }\end{array}$ & 8954.5 & 2.37 & 2 \\
\hline $\begin{array}{l}\text { Chemical materials and chemical } \\
\text { products manufacturing }\end{array}$ & 14105.6 & 1.36 & 6 & Handicraft and other production & 179.2 & 0.10 & 17 \\
\hline Pharmaceutical manufacturing & 11913.9 & 1.34 & 7 & $\begin{array}{l}\text { Electricity, gas and water production } \\
\text { and supply }\end{array}$ & 5092.9 & 0.06 & 20 \\
\hline Rubber products & 50.0 & 0.10 & 17 & $\begin{array}{l}\text { Electricity and heat production and } \\
\text { supply }\end{array}$ & 5092.9 & 0.07 & 19 \\
\hline Plastic products & 535.4 & 0.09 & 18 & & & & \\
\hline
\end{tabular}

Sources: except the special indication, all the data in the paper come from the "Data Bulletin of the Second R\&D Resources Inventory in Wuhan” by Wuhan Statistic Bureau, Scientific and Technological Bureau, Development and Reform Commission, and Finance Department, February 21, 2011 'Input intensity of R\&D expenditure in the industrial enterprises means the ratio between R\&D expenses and the main business income

R\&D Projects: In 2009, the industrial enterprises had 3091 projects in R\&D and the full time equivalent of R\&D staffs got to 17048 personnel/year and the concerned funds are 4.39 billion yuan. Based on the technology economy of projects, the funds to develop the brand new products occupied 70\%; those for increasing the product functions or performance, 19.6\%; those for reducing the energy consumption or raising its use efficiency, $4.5 \%$; those for the productivity rise, $1.0 \%$; for reducing the environmental pollution, $1.9 \%$; for the research of technological principles, $0.3 \%$; for the raw materials saving, $0.9 \%$; for the others, $1.8 \%$.

According to the project sources, the project funds from the enterprises accounted for $77.2 \%$; from the local government, 3.1\%; from the central government, $10.2 \%$; entrusted by the other enterprises, $5.2 \%$; from the others, $4.3 \%$.

In light of the cooperative forms, the projects accomplished by the enterprises themselves in funds occupied 78\%; cooperated with the higher educational universities, $10.1 \%$; with the independent research institutes at home, 2.8\%; with the other enterprises inside the country, 2.9\%; with the organizations outside the country, $2.1 \%$; others, $4.1 \%$.

R\&D Organizations Opened by the Enterprise: Up to 2009, various R\&D organizations in Wuhan have been set up; of which 229 belong to the industrial enterprises. In the latter, the staffs who are engaged in R\&D activities have reached 22478 and are 2.1 times of those in 2000. Doctors and masters are 8542 and occupy 38\%. The funds for R\&D in the organizations of the industrial enterprises are 3.89 billion yuan and 7.9 times of those in 2000, of which those for apparatus and equipments in science and technology are 9.25 billion yuan and 4.3 times of those in 2000 .

Outcomes from the R\&D Activities: In 2009, the industrial enterprises realized a output value of new products of 96.12 billion yuan that was 9.1 times of that in 2000. The sales income of new 
products of the whole year got to 95.60 billion yuan and was 9.3 times of that in 2000 . The ratios that the sales income of new products accounted for that of main businesses were $16 \%$ and were raised by 2.9 percentages compared with that in 2000 .

In 2009, the industrial enterprises had 3899 patent applications, which were 7.5 times of those in 2000, among which the patent for invention was 1404 and 6.6 times of that in 2000, occupying 36\% (see Table II).

TABLE II. OUTCOMES OF R\&D ACTIVITIES IN 2009

\begin{tabular}{|l|l|l|l|}
\hline $\begin{array}{l}\text { Output value of New Products } \\
(100 \text { million yuan })\end{array}$ & $\begin{array}{l}\text { Sales income of new products } \\
(100 \text { million yuan })\end{array}$ & \multicolumn{2}{l|}{$\begin{array}{l}\text { Patent application from the industrial enterprises } \\
\text { (piece })\end{array}$} \\
\hline & & & Invention patent ( piece $)$ \\
\hline 961.16 & 955.97 & 3899 & 1404 \\
\hline
\end{tabular}

\section{Features of R\&D Personnel Development in Wuhan Industry}

The organizations to develop the talents grow fast, but the fields are to be adjusted: The platforms to develop the talents mainly include R\&D organization and project construction. As for the organizations, compared with those in 2000, either quantity or personnel that are engaged in R\&D or funds or apparatus or equipments were greatly raised in 2009 and this has provided a good environment to develop innovative talents for the industrial enterprises in Wuhan.

In the project construction, 70\% funds in Wuhan have been invested into the development of brand new products, which mean those that adopt the new technological principles, new design in production. The inputs in energy saving, raising the efficiency of using energy and the productivity only occupied respectively $4.5 \%$ and $1 \%$; those in reducing pollution, only $1.9 \%$; those in saving raw materials, $0.9 \%$. Such kind of input ratios has produced a distance from the demands to transform and upgrade the industry intensively in the 12th five-year plan. So, R\&D inputs in saving energies and raw materials, raising the efficiency of using the resources and clean production, etc. should be strengthened so as to guide the talents move into these fields.

Cooperative hierarchy of the projects to be raised in developing talents: The projects of the industrial enterprises are the aggregation to attract and gather the talents. According to the project cooperative forms in Wuhan, mainly categories include: projects finished independently by the enterprise; those done cooperatively with the higher educational institutions at home; those cooperatively with the independent research institutes in China; those cooperatively with the other firms inside China; those cooperatively with institutes outside China. Among these categories, the first accounted for $78 \%$ and the rest occupied a small proportion. The situation explains that the industrial enterprises in Wuhan have had relatively strong self-dependent R\&D ability, can finish the R\&D activities by themselves, which is helpful to owning the R\&D outcomes on the one hand; but on the other hand, it does no good in which the enterprises join in the global competition because little cooperation with the outer intelligent resources, particularly with those leading the international industrial level has been done. The reality of the brand products with "MADE IN WUHAN" proves the situation: up to the end of 2009, of Wuhan brands, 19 famous in China, 49 in Hubei; 14 well-known trademarks in China, 65 in Wuhan, but few brands or trademarks well-known in the world[1]. Therefore, to compete with the global enterprises, Wuhan must introduce the intelligent resources with international leading level as soon as possible in the period of transformation and upgrading. It is the essential approach to raise the level of the industrialization in Wuhan.

High recognition of the output from $R \& D$ by the market: In recent years, the outputs from the use development of the talents in Wuhan industry have been increasing by double times every year whether in the output value of new products or in their sales income. In the patent application of the industrial enterprises, the quantity rises fast and the invention patent application accounts for a larger proportion. The invention patent mainly includes that of products and methods. The former refers to the technological proposal about various new products, new materials and new substances by $R \& D$. It may be an independent and complete product, or parts and components in the 
equipment or apparatus, and its primary content consists of manufacturing products like machines, equipments and various materials such as chemical substances and composition. The latter means the technological proposals in operation, manufacturing and process made out in order to manufacture products or solve a certain technological issue. It mainly consists of approaches in manufacturing, measuring, analyzing and telecommunication, etc. The fast increase in the output value, sales income and invention patents of new products in Wuhan industry says that the innovative potentials of the talents have been remarkably developed and that the creative labor of the talents is more targeting and more recognized in the market.

\section{Conclusions and Enlightenment in Developing the Innovative Talents in the Industrial Transformation and Upgrading in Wuhan}

Analyzing the actual situation developing R\&D talents in Wuhan, we can be enlightened as follows:

First, the industrial transformation and upgrading requires a change of the production mode, namely, that from the traditional production one with high energy consumption, high pollution to the one with low energy consumption and low pollution. This change requires that the enterprises should increase the hi-tech content in the processing and materials and the rise of technological levels and the technological innovation can't be kept away from the creative work of the talents. It demands the enterprises to be based on the hi-tech project promote the application of the hi-tech in the environmental protection and guide the talents flow into these fields.

Then, the industrial enterprises in Wuhan also need to highlight the introduction of the intelligence resources with international level and elbow their way to join in the international competition by introducing international projects or increase the supports to the international cooperative item.

Next, the industrial transformation is the change of the commercial service model. The new commercial model aims at realizing value-added service by inner business process, design of the basic framework and integrating the outer resources so as to segment the market and create demands on the base of internet and new technology. The commercial model is another innovation following that of the technology, products and organization and a remarkable feature of new economy. Its core to transform its model lies in talents, or in developing the talents familiar both with technology, with management and with market.

\section{Acknowledgement}

The paper is supported both by the MOE Project of Key Research Institute of Humanities and Social Science in University Wuhan and by the Research Centre on the Development of the Manufacturing Industry of the Wuhan City Circle, China.

\section{References}

[1] Zhihong Li, Wenqing Wang, Dong Liang, Study on the Industry in Wuhan 2010, Wuhan University Press, December, 2010 (in Chinese).

[2] Chen Yuandun, Chen Quanming. (2001), Development and management of human resources [M], Chinese Statistics Press, (in Chinese).

[3] Ye Jihong, Exploring the Management Model of Personal Development in Suzhou Industry Park, Science of Science and Management of S\&T, 2000,21(7), (in Chinese).

[4] Zhang Yanlin, Sun Shuyi. (2005). Report of the Chinese enterprises [M], Enterprise Management Press, (in Chinese).

[5] Yue Longhua, Study on the Development of the Talenets in the Soft Industry in China, Xi Nan Finance University, 2005 (in Chinese). 